\title{
Assessment of Seed-Borne Plant Pathogenic Fungi Associated with Rice Crop in South-Eastern Nigeria
}

\author{
Christian Chukwunenye, Iwuagwu ${ }^{1}$, Charles Ikechukwu, Umechuruba ${ }^{2}$, Charles Chimezie, Ononuju ${ }^{3}$ and Andrew \\ Chukwuma Nwogbaga ${ }^{4}$ \\ 1. Department of Crop Science and Horticulture Nnamdi Azikiwe, University Awka, Anambra State, Nigeria \\ 2. Evangel University Ikpoto, Ebonyi State, Nigeria \\ 3. Department of Plant Health Management, Michael Okpara University of Agriculture, Umudike, Abia State, Nigeria \\ 4. Department of Crop Production and Land Scape Management, Ebonyi State University, Ebonyi, Nigeria
}

\begin{abstract}
This study was conducted to assess the incidence of seed-borne fungi on rice seeds sourced from the major rice growing areas of South-Eastern Nigeria. The rice seeds were collected during the dry seasons between 2009 and 2010. Four hundred rice seeds randomly collected and surface sterilized by washing in 3\% sodium hypochlorite and rinsed two times with sterile distilled water were placed in three circular rings inside the Petri dishes. The incubation was done one after the other for each variety from all the locations. Ten fungi species from eight genera were isolated from the rice seeds in all the rice growing areas of South-Eastern Nigeria. The fungi pathogens vary from one locality to another, as well as the frequency of occurrence. The pathogens isolated include: Fusarium moniliforme, F. solani, F. oxysporium, Aspergillus spp., Botridiploidia spp., Helminthosporium spp., Penicillium spp., Trichoconis padwickii, Curvularia oryzae and Phoma oryzae. Though, there was the presence of some seed-borne fungi in the rice seeds from the areas studied, most of the cultivars experienced up to $90 \%$ germination. But some cultivars had very low germination. IR 1416 from Arochukwu and GB90 from Arondiuzogu had less than 1\% germination. This study shows that seed-borne organisms are major constraint in rice production in the South-Eastern states of Nigeria as a result of low seed germination stemmed from infestation of fungi organisms in the seeds.
\end{abstract}

Key words: Mycoflora, rice seeds, germination, South-Eastern states.

\section{Introduction}

Rice (Oryzae sativa L.) is one of the world's primary food crops mostly grown in tropical and sub-tropical climate. It is main staple food in Nigeria. Demand for rice in Nigeria is growing faster than that for any other staples with consumption broadening across all socio-economic classes. Nigeria has been identified to consume about 5.4 million metric tons of rice annually (valued at over $\$ 9.2$ billion at current prices), while local production amounts to 2.3 million metric tons per year and that of the remaining 3.1 million metric tons is imported. Nigeria is the second largest importer of rice in the world by the year 2003

Corresponding author: Christian Chukwunenye, Iwuagwu, Ph.D., research field: plant pathology.
[1]. According to Omofonmwan and Kadiri [2], the second most serious problem confronting Nigeria rice farmers is the devastation caused by pests and diseases coming after the problem of finance. The south-eastern agro-ecological zone has the potential for achieving national self sufficiency in rice production. However, the yield of this crop has never been able to meet the growing demand as a result of disease infestation [2].

Seed health testing to detect seed-borne pathogens is an important step in the management of crop diseases [3]. It identifies the cause of seed infection that affects the planting value of seed lots for seed certification by seed growers to supply seeds to farmer. Seed testing affects policies on seed improvement, seed trade and plant protection. 
Several routine activities are undertaken during seed health testing. These include dry seed inspection, the standard blotter test for seed infection and contamination, post entry planting for field inspection of undetected plant diseases of seed-borne and seed-contaminated pathogens and certification [4, 5]. Seed health testing procedure involves techniques, such as direct examination of dry seeds, examination of germinated seeds, examination of organism removed by washing and examination after incubation (both blotter and agar plates). Ibiam et al. [6] and Ito et al. [7] observed that some fungi pathogens borne on rice seeds are better deleted by using different seed health testing techniques. According to their observation, using blotter, agar plate and deep freezing techniques, the blotter method was found suitable for the detection of Alternaria alternate, A. tenuissima, Aspergillus niger, A. flavus, A. terreus, Chaetomium globosum and Curvularia spp. were isolated more on agar plate and Fusarium spp., Trichoconis padwickii, Myrothecium roridum were detected more where deep freezing technique was used. Also, several fungal pathogens have been isolated from rice and have been reported to be responsible for a number of disease right from nursery to the field [6, 8]. Also, Ora et al. [3] reported that in a study carried out in Punjab, Pakistan on the mycoflora of stored rice grains, some fungi pathogens were isolated. The pathogens included: F. moniliforme, Alternaria sp., Helminthosporium sp. and Curvularia sp. According to them seed-borne diseases caused by fungus are relatively difficult to control as the fungi hyphae get established and become dormant.

Due to climate change, emerging, re-emerging and endemic plant pathogens continue to be a challenge in safeguarding plant health in the South-Eastern Nigeria [3]. Therefore, early and accurate diagnoses and pathogen surveillance will allow time for development and application of mitigation strategies. This study was conducted to assess the incidence of seed-borne fungi and their impact on seed germinations of rice seeds from major rice growing areas of South-Eastern Nigeria.

\section{Materials and Methods}

Rice seeds were collected from local rice farmers from the major rice producing localities of the South-Eastern states of Nigeria. The number of varieties collected depended on the available ones planted in each area. The states visited included: Abia, Anambra, Ebonyi, Enugu and Imo. The rice varieties included: FARO 48, local variety, BG 90, FADAMA, FARO 57, FARO 51, IR 1416, FARO 52, FARO 15, NERICA, SML, FARO 44 and R-BUS. The number of rice varieties used per local government area was determined by ones available at the time of the survey. From Ebonyi State four varieties were collected, which included: FARO 44, FARO 52, NERICA and one local variety, from Enugu State, five varieties: BG, FADAMA, FARO 15, IR 1416 and one local variety, from Abia, eight varieties: FARO 44, FARO 52, FARO 57, FARO 51, NERICA, SML, IR 1416 and one local variety, from Anambra State, three varieties: FARO 44, FARO 48 and IR 1416, from Imo State, three varieties: FARO 54, MBG 90 and one local variety.

The rice seeds were collected during the dry seasons between 2009 and 2010. Rice seeds were packaged in brown envelopes according to their varieties, and localities were taken to the Pathology Laboratory for mycological studies in the Pathology Laboratory of Department of Plant Health Management, Michael Okpara University of Agriculture Umudike, Abia State, Nigeria. Blotter paper method was used [4]. Sixteen Petri dishes $(9 \mathrm{~cm}$ diameter) with three layers of blotter paper of $9 \mathrm{~cm}$ were used for each variety. Four hundred rice seeds randomly collected and surface sterilized by washing in $3 \%$ sodium hypochlorite and rinsed two times with sterile distilled water were placed in three circular rings inside the Petri dishes. The incubation was done one after the other for each variety from all the locations. The fungi pathogen seen growing from rice 
seeds were isolated and transferred into Petri dishes that contain potato dextrose agar (PDA), acidified with lactic acid. Five plates were used for each suspected fungus. The dishes were kept in incubator with $12 \mathrm{~h}$ of alternating light and darkness at a temperature of $27 \pm 2{ }^{\circ} \mathrm{C}$. Sub-culturing was carried out until pure cultures were obtained. Fungi growing out of the seeds were examined on pure cultures and identified by using identification guides by Barnett and Hunter [9] and Alexopoulos et al. [10]. Identification and characterization were carried out with the use of stereo binocular and compound microscopes (Olympus $\mathrm{CH}$ ). Identification was based on the characteristics of the mycelium and fruiting body of each fungus. Percentage incidence of each fungus from each variety was recorded as well as the micrographs. The percentage disease incidence was determined by using the formula as was suggested by Snedechor and Cochran [11] as follows:

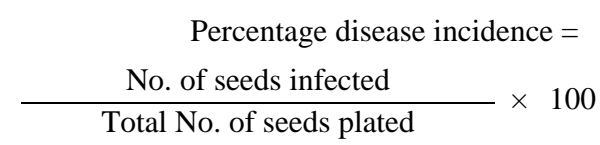

\section{Results}

3.1 Plant Pathogenic Fungi Associated with Rice Seeds

The result of assessment of seed-borne fungi associated with rice seeds from across the South-Eastern Nigeria showed that about nine genera of fungi were identified and eleven species of them were isolated and identified. These include: F. moniliforme, F. solani, F. oxysporum, Rhizopus sporangia, Aspegillus spp., Penicillium spp., $H$. oryzae, $T$. padwickii, Phoma oryzae, Botridiploidia spp. and $C$. oryzae (Tables 1 and 2, Fig. 1).

The results (Tables 1 and 2) also showed that $F$. moniliforme was the most occurring fungi which was isolated from twelve rice varieties out of the thirteen studied. This fungus was followed by Aspergillus and Penicillium (Fig. 1) genera which were isolated from seven different rice varieties. The third fungus found in order of importance was $F$. solani and T. padwicki which had occurrence in five different varieties each. The least fungus detected was $C$. oryzae which was isolated from only two varieties of rice.

Table 3 showed the frequency of fungi pathogens isolated from each rice variety from the areas under study. Local variety (kpurukpuru) had the highest number of isolated fungi organisms followed by FARO 48, while the varieties with the least number of fungi organisms were FARO 44, FARO 51 and NERICA, which had one fungi organism each. $F$. moniliforme (plate b) had the highest number of occurrence. It was isolated from ten rice varieties out of 13 varieties studied, followed by Penicillium spp. (plate f), which was isolated from six rice varieties, but the organisms with the least occurrence were Botridiploidia spp. (plate h) and C. oryzae (plate d), which were isolated from two and three rice varieties, respectively.

\section{Discussion}

\subsection{Assessment of Incidence and Severity of Disease} Pathogens

The result of the disease survey in rice producing areas of South-Eastern Nigeria revealed that rice seeds collected from the various rice producing communities were infected by fungi organisms. These fungi organisms were isolated from the rice seeds after careful seed health tests were conducted. The organisms isolated included: $F$. moniliforme, $P$. oscilicum, F. solani, Aspergillus etc. from rice seeds from Abia States. Most of these fungi organisms have been found to be pathogenic to rice plant, causing various damages, such as loss of viability, poor seedling growth, poor rice stand, poor yield and generally economic loss to rice farmers in the South-Eastern Nigeria and Nigeria as a whole. This result agrees with the earlier work of Imohelin [12], which isolated fungi organisms, such as $H$. oryzae, $C$. orzzae, Aspergillus spp. etc. from rice seeds in Edo 
Assessment of Seed-Borne Plant Pathogenic Fungi Associated with Rice Crop in South-Eastern Nigeria

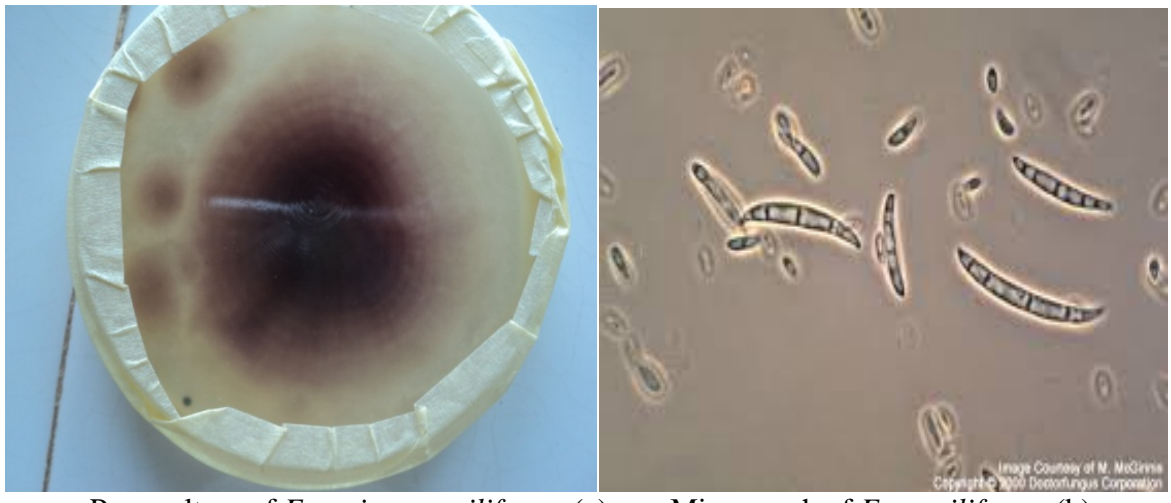

Pure culture of Fusarium moniliforme (a) Micrograph of F. moniliforme (b)

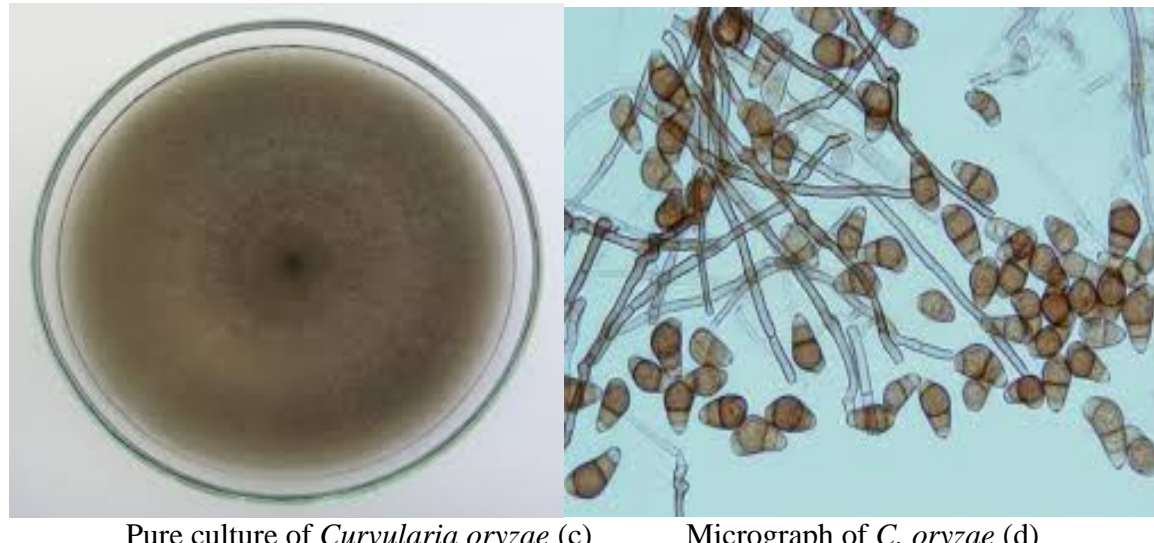

Pure culture of Curvularia oryzae (c)

Micrograph of C. oryzae (d)

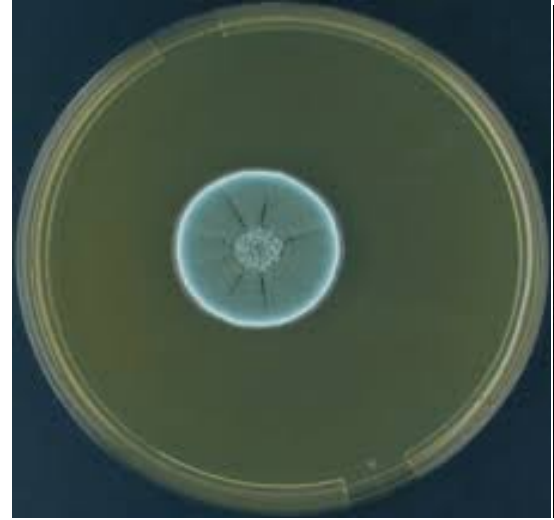

Pure culture of Penicillium spp. (e)

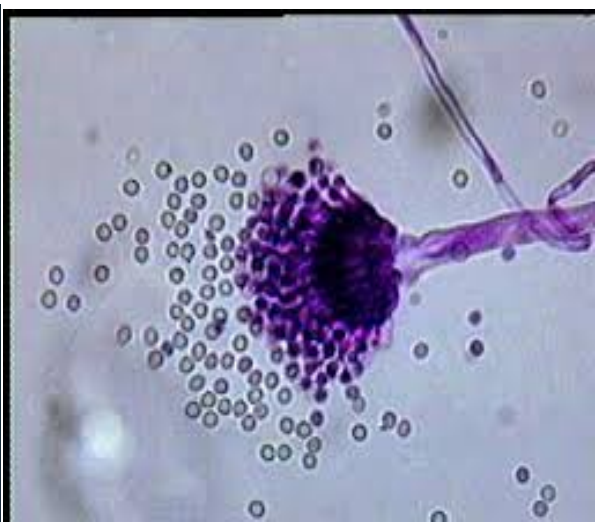

Micrograph of Penicillium spp. (f)

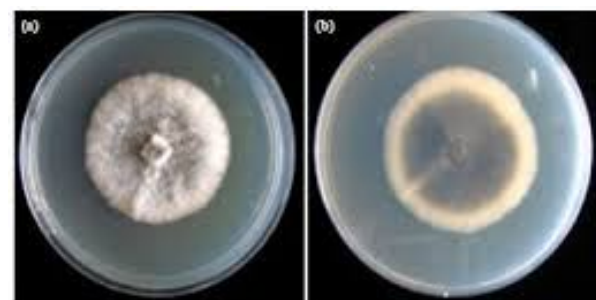

Pure culture of Botryodipoidia spp. (g)

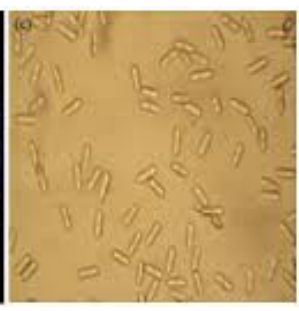

Micrograph of Botryodipoidia spp. (h)

Fig. 1 Fungi organisms isolated from rice seeds in South-Eastern states of Nigeria.

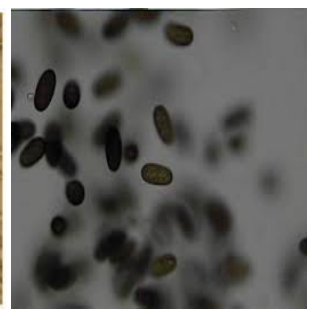




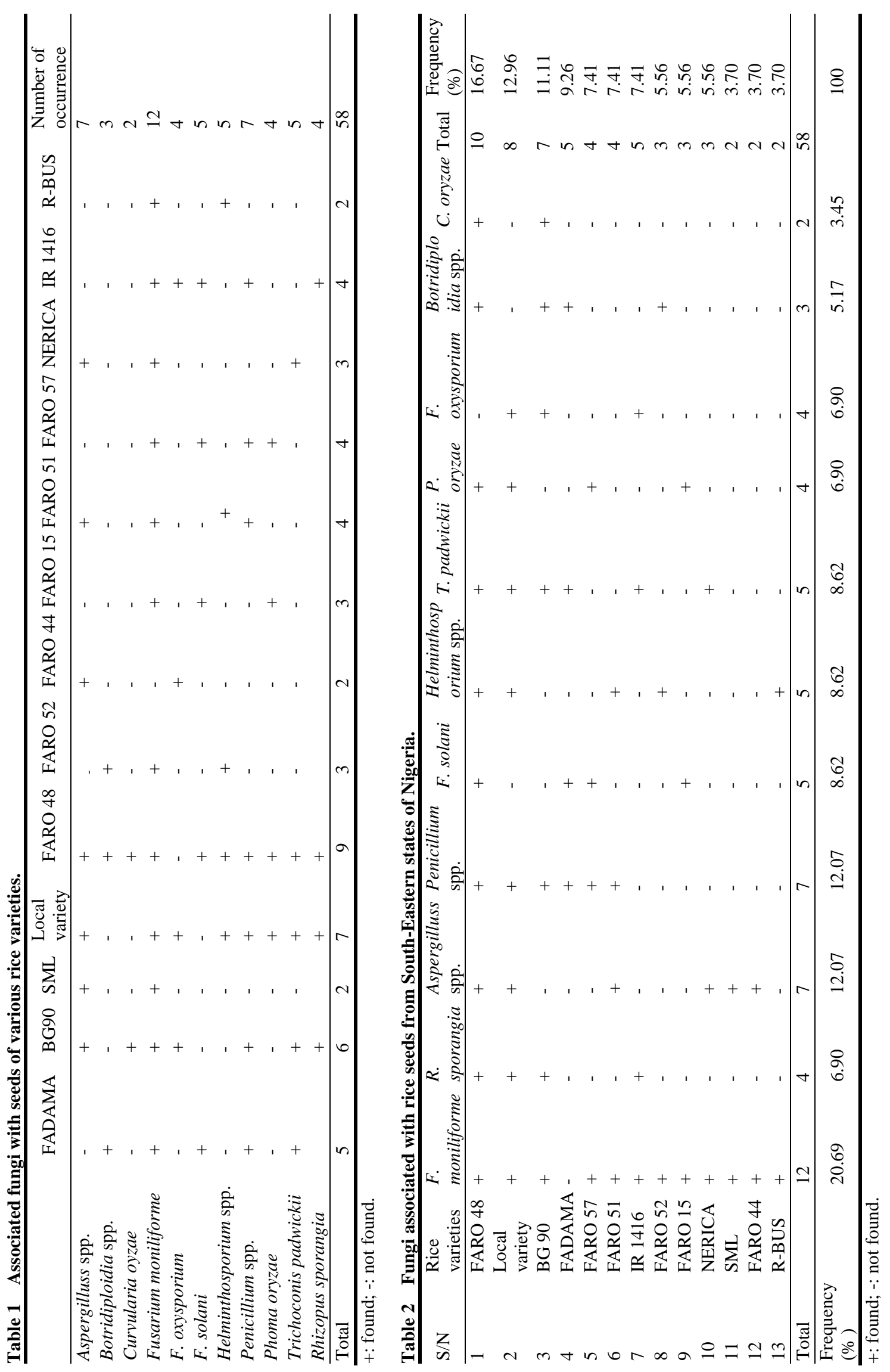


Table 3 Seed-borne fungi pathogens isolated and mean infection levels (\%) in various samples across rice growing areas of South-Eastern Nigeria.

\begin{tabular}{lll}
\hline Site & Pathogen & Incidence (\%) \\
\hline Arochukwu & F. moniliforme & 99.56 \\
Ohofia & F. moniliforme & 11.00 \\
Bende & F. solani & 4.13 \\
Umnahia South & Aspergillus spp. & 17.00 \\
Omor & Botridiploidia spp. & 23.45 \\
Ifite Ogwari & Helminthosporium spp. & 57.64 \\
Anaku & Penicillium spp. & 27.33 \\
Otuocha & Botridiploidia spp. & 11.62 \\
Izzi & F. moniliforme & 3.00 \\
Ezza & F. solani & 2.23 \\
Abakiliki & Trichoconis padwickii & 34.17 \\
Isiagu & Rhizopus spp. & 24.67 \\
Adani & F. moniliforme & 2.00 \\
Ehamufu & Curvularia oryzae & 1.25 \\
Nkamu East & Phoma oryzae & 11.27 \\
Oji River & Aspergillus spp. & 13.12 \\
Arondiuzogu & F. oxysporium & 99.52 \\
Okata & F. moniliforme & 5.13 \\
Onicha Uboma & F. oxysporium & 16.46 \\
Onuimo & Penicillium spp. & 7.54 \\
\hline & &
\end{tabular}

State of Nigeria. He posited that F. moniliforme being the third highest frequently occurring organisms in that zone has been known to cause poor seed germination discoloration of rice seeds. Also, its frequent isolation from rice seeds indicates that it may contribute to poor seed quality of Nigerian processed rice he pointed out.

A. niger was also isolated from rice seeds from Abia State. This result is in accordance with the result of Imohelin [12], which isolated A. aterhizus from rice seeds in Edo State. Just as was observed in this study, these organisms although regarded as surface contaminants were frequently observed on rice seeds. Besides the fact that some Aspergillus spp. produce aflatoxins, they have been shown to decay stored grains. These studies have associated these fungi with reduced germination of seeds in the laboratory. These fungi, like rice pathogens, are therefore of economic importance in Nigeria rice production.

$H$. oryzae was also identified as one of the fungi isolated from rice seeds from Anambra State. Other fungi isolated included Botrydiploidia spp., $P$. osilicum, A. niger. This result corroborates with the report of Suleiman and Akaajime [13], which isolated $H$. oryzae from Abakaliki rice producing areas. The high frequency of isolation of this pathogen from this area may explain in part the high incidence of brown leaf spot. According to Utobo et al. [14] and Suleiman and Akaajime [13], this pathogen may pose a serious threat to the rice industry in the area if adequate control measures are not implemented.

A. niger was one of the highest pathogens isolated from the area. This result is in agreement with the work of Suleiman and Akaajime [13] who isolated $A$. niger and $R$. oryzae from rice seeds in the area of study. According to them, although these organisms are regarded as surface contaminants, they were also frequently observed on infected rice grains. Also besides the fact that some Aspergillus spp. produces aflatoxins, they have also been shown to deteriorate stored grains. T. padwickii was isolated from rice seeds from Abakaliki area and from the plant materials in the nursery and field. This result is similar to the work of Utobo et al. [14] who reported that $T$. 
padwickii was the most frequently isolated seaborne fungi irrespective of the source of the rice variety tested in their study.

\subsection{Incidence and Severity of Major Disease Pathogens}

The result of survey of incidence and severity of many fungi disease pathogens in different local government areas of the states showed that, there were varied fungi pathogens prevalent in various states and local government areas. This result is similar to the report of Refs. [6, 8, 14, 15]. Also, Ora et al. [3] reported that there were several fungi disease pathogens attacking rice plants at various areas in the same state or province. They reported that different fungi pathogens attack rice plants and seeds in the field and store at different locations of a given area or state/province. Ibiam et al. [6] reported that $F$. moniliforme, Bipolaris oryzae, F. oxysporum, A. niger, A. flavas, A. terreus, A. terruis and Penicillin spp. were isolated and identified from seeds of three varieties of rice (FARO 12, FARO 15 and FARO 29) during storage; and F. oxysporum, Chactomium globosum, C. lunata and Trichoderma harzianum from the seeds of three rice varieties in the field of Afikpo area; while Utobo et al. [14] isolated and identified: $R$. oryzae, T. padwickii, $H$. oryzae, $F$. moniliforme, A. niger, C. lunata, Penicullium spp., A. oryzae, Pyricularia oryzae from rice seeds from various locations in Abakiliki. They also reported that among the isolated fungi pathogens, there were one or two of them that were most predominant as were observed in this study. Utobo et al. [14] reported that among the fungi pathogen isolated, T. padwickii was the most predominant. Ibiam et al. [6] also reported that $F$. moniliforme was more prevalent than other fungi both in the field and storage in Afikpo North Local Government Area. Butt et al. [8] also reported that $H$. oryzae was the most frequently isolated seed-borne fungus regardless of the source of rice cultivars tested in Edo State.
It was also observed in this study that there was significant difference in incidence and severity of a particular disease caused by the same fungi pathogen in different local government areas of each state. The reason could have been as a result of different biophysical, socio-economic and crop management factors in the different areas studied [4]. According to them, among the biophysical factors, source of irrigation, weed and pest pressure are significant determinant in disease incidence and severity and consequently on.

\section{Conclusions}

The study has shown that seed-borne organisms are major constraint in rice production in the South-Eastern states of Nigeria as a result of low seed germination stemmed from infestation of fungi organisms in the seeds. Therefore, the farmers should carry out adequate seed health test before embarking on their rice production to minimize crop failure as a result of poor seed germination caused by fungi infestation. Also, the famers should be able to source their rice seeds from reliable seed handlers.

\section{References}

[1] Ezeji, J. 2009. "The Travails of Nigerian Rice." http://joachimibeziakoezeji.blogspot.com/2009/06/travails -of-nigerian-rice.html.

[2] Omofonmwan, S. I., and Kadiri, M. A. 2007. "Problems and Prospect of Rice Production in Central District of Edo State.” Nigeria Journal of Humid Ecology 22 (2): 123-8.

[3] Ora, N., Farua, A. N., Islam, M. T., Akhtar N., and Rahman, M. M. 2011. "Detection and Identification of Seed Borne Pathogens from Cultivated Hybrid Rice Varieties in Bangladesh.” Middle-East Journal of Scientific Research 10 (4): 482-8.

[4] Mew, T. W., and Gonzales, P. 2002. Handbook of Rice Seed-Borne Fungi IRRI. Metro Manila: Science Publisher Inc., 3-56.

[5] Khan, I. A., Zubar, M., and Malik, B. A. 2000. "Various Seed Rates Affect Yield and Yield Components of Mash." Pakistan Journal of Agricultural Research 9: 165-7.

[6] Ibiam, O. F. A., Umechuruba, C. I., and Arinze, A. E. 2008. "A Survey of Seed Borne Fungi Associated with Seeds of Rice (Oryzae sativa L. FARO 12, 15 and 29) in 

Rice Crop in South-Eastern Nigeria

Storage and in the Field in Afukpo North Local Government Area of Ebonyi State.” Scientia Africana 7 (2): 1-5.

[7] Ito, M. A, Bacchi, L. M. A., Maringoni, A. C., and Menten, J. O. 1992. "Comparison for the Detection of Aspergillus and Penicillium spp. on Gruodnut Seeds.” Suma Phytopathological (Brazil) 18: 262-8.

[8] Butt, A. R., Yaseen, S. I., and Javaid, A. 2011. "Seed-Borne Mycoflora of Stored Rice Grains and Its Chemical Control.” Journal of Animal and Plant Sciences 21 (2): 193-6.

[9] Barnett, H. L., and Hunter, B. B. 1999. Illustrated Genera of Imperfect Fungi (4th Edition). St. Paul, Minoesota: The American Phytopathological Society, 218.

[10] Alexopoulos, C. J., Mims, C. W., and Blackwell, M. 2002. Introductory Mycology (4th Edition). Hoboken, NZ: John Wiley and Sons, Inc.

[11] Snedechor, G. W., and Cochran, W. G. 1994. "Statistical
Methods.” Journal of Education and Behavioural Statistics 19 (3): 304-7.

[12] Imohelin, E. D. 1983. "Rice Seed Borne Fungi and Their Effect on Seed Germination.” Plant Diseases 67 (12): 1-3.

[13] Suleiman, M. N., and Akaajime, D. 2010. "Isolation and Physiological Studies of Fungus Associated with Rice Grain (Oryza stativa) in Makurdi, Benue State.” Nigeria Advances in Governmental Biology 4 (2): 168-71.

[14] Utobo, E. B., Ogbodo, E. B., and Nwogbaga, A. C. 2011. "Seed Borne Mycoflora Associated with Rice and Their Influence on Growth at Abakiliki, Southeast Agro-Ecology, Nigeria. Libyan Agriculture Research Centre.” Journal International 2 (2): 79-84.

[15] Diaz, C., Hossain, M. S., and Mew, T. 1998. "Seed Quality and Effect on Rice Yield: Findings from Farmer Participatory Experiments in Central Luzon, Philippines.” Philippines Journal of Crop Science 23 (2): 111-9. 